\title{
PREVALENCE OF TICK-VECTORS OF THEILERIA ANNULATA INFESTING THE ONE-HUMPED CAMELS IN GIZA, EGYPT
} \author{
By \\ MOSTAFA I. HASSAN ${ }^{1}$, HANAN S. M. GABR ${ }^{2}$, SOBHY ABDEL-SHAFY ${ }^{3}$, \\ KOTB M. HAMMAD ${ }^{1}$ AND MOSTAFA M. MOKHTAR ${ }^{1^{*}}$
}

Department of Zoology and Entomology, Faculty of Science ${ }^{1}$, Al-Azhar University, Nasr City, Cairo, Department of Zoology and Agricultural Nematology ${ }^{2}$, Faculty of Agriculture, Cairo University, Giza, and Department of Parasitology and Animal Diseases $^{3}$, Veterinary Research Division, National Research Centre, Dokki, Giza, Egypt ( ${ }^{\star}$ Correspondence: drmosta80@gmail.com)

\section{Abstract}

Theileria are obligate intracellular protozoan parasites transmitted by hard ticks that cause severe and mild infections in their vertebrate hosts. The objective of the present study was to identify the possible tick vector of Theileria spp. and to determine the prevalence of camel theileriosis in Birqash market, Giza, Egypt. These camels are previously imported from Sudan and Somalia. A total of 298 nomadic one - humped camels in the study area were selected by simple random sampling technique during the period from December 2014 to November 2015. A total of 1540 ticks were collected, four ixodid tick species; Hyalomma dromedarii, Amblyomma lepidum, Amblyomma variegatum, and Rhipicephalus pulchellus were found on camels. It was observed that $H$. dromedarii recorded the highest prevalence (69\%), followed by A. lepidum (8\%), A. variegatum (3\%) and R. pulchellus (2\%). Using light microscope Hyalomma dromedarii was the most tick carrier of Theileria spp. which recorded $1.3 \%$ (20/1540) Theileria infection. The highly prevalence rates for all ticks were monitored during the summer season. The molecular detection of Theileria annulata in Geimsa-stain positive H. dromedarii ticks was performed by the PCR using primer set N516/N517 derived from the gene encoding the $30 \mathrm{kDa}$ major merozoite surface antigen. This primer set amplified $T$. annulata in $H$. dromedarii at $750 \mathrm{bp}$. Thus the presence of $H$. dromedarii on camels in the field have dangerous inclusive for animal health and to some extent humans. To reduce these dangerous effects, strategic control methods could be used in the control of ticks.

Keywords: Amblyomma, Hyalomma, Rhipicephalus, Ixodidae, Prevelance, Theileria; 30KDa

\section{Introduction}

Ticks are the most important vectors that infest animals and transmit a wide range of pathogens. Ticks are considered as vertebrate's vectors and constitute the largest tick genera with about 235 different species described worldwide (Norbert. 2013). The ticks, as obligate blood-sucking ectoparasites, attack a broad range of vertebrates, including humans. They are viewed as second just to mosquitoes as vectors of pathogens for domestic and wild animals (de la Fuente et al, 2007). They transmit medical and veterinary pathogens including viruses, bacteria, and protozoans, all of which cause damage to livestock production. The onehumped camel, Camelus dromedaries is an important multipurpose animal. It has been used for transportation and produces milk, wool and meat in arid and semi-arid areas of the world (Kamani, 2008). Also, camels are hard animals and can tolerate the harsh conditions of arid regions because of their unique adaptive physiological characteristics. (Swelum et al, 2014).

Theileriosis is one of the most common tick-borne diseases, which have been studied and described in a wide range of livestock such as cattle, sheep, and goats. Few studeid theileriosis infected camels (Nassar, 1992; Abd El-Baky, 2001; El Kammah et al, 2001; El-Fayoumy et al, 2005; Youssef et al, 2015). Theileria spp. is tick-trans-mitted, intracellular protozoan parasites infecting leukocytes and erythrocytes of a wide range of animals (Shaw et al, 1991; Bishop et al, 2004). The organisms have been described in all livestock species and can 
cause significant economic losses to farmers. They are transmitted by a variety species of the ixodid tick Hyalomma (FlorinChristensen, and Schnittger, 2009).

In Egypt, the most common tick species infesting camels in Sinai Peninsula are $H$. dromedarri and $H$. impeltatum, they transmitted the infective stage of Thelieria via their guts, salivary glands and hemolymph (El-Kady, 1998).

Detection of these blood parasites is highly helpful in early diagnosis and treatment. Classical, microscopy using Giemsa-stained hemolymph from ticks has proven to be the first method for detecting Theileria organism in the ticks, but not in all tick-vectors, where Theileria was low (Hamed et al, 2011). Application of polymerase chain reaction (PCR) proved valuable in diagnosing Theileria in ticks (Zhang et al, 2014).

The present study was designed to achieve the two objectives: 1) Updated knowledge about the ixodid ticks infesting camels from Giza Birqash Camel Market (Souq alGamal). 2) Determination of tick(s) naturally infested with Theileria spp. to identify the possible tick vector and to determine the prevalence of camels' theileriosis in Birqash Market, using Giemsa-stained tick hemolymph smears, and PCR assay.

\section{Materials and Methods}

Study area: All ticks were collected from camel market at latitudes $30^{\circ} 08^{\prime} 57.1^{\prime \prime} \mathrm{N}$ and longitudes $30^{\circ} 59^{\prime} 42.8^{\prime \prime} \mathrm{E}$, Birqash village, Giza Governorate, Egypt. Temperature and relative humidity were monitored monthly in the studied area from December 2014 to November 2015.

Ticks collection: The camels were sampled for ticks on head, shoulder, belly, and perineal regions using curved forceps. The samples were transported alive to Laboratory Animal Acarines Research, Faculty of Agriculture, Cairo University. They were incubated at $28 \pm 1^{\circ} \mathrm{C} \& 75 \pm 5 \%$ relative humidity. Locality (Global Positioning System G.P.S.), host, date, climatic condition (temperature and relative humidity), and infestation sites were recorded. The identification of ticks was confirmed in the laboratory using standard keys (Hoogstraal, 1956; Walker et al, 2003).

Tick hemolymph smear preparation: Hemolymph was collected individually for examination with $100 x$ magnifications using lightmicroscope for any stages of tick species and then stored at $-20^{\circ} \mathrm{C}$ (Burgdorfer, 1970).

DNA Extraction: From every month, $25 \%$ tick samples were divided into 5 ticks in one pooled sample. The frozen ticks were cut into small pieces using a disposable scalpel in $1.5 \mu \mathrm{L}$ Eppendorf tubes under a sterile laminar flow hood, Molecular Biology Laboratory, Department of Zoology, Faculty of Science, Menoufia University. DNA was extracted from the ticks using the PureLink ${ }^{\circledR}$ Genomic DNA Kits (Invitrogen, USA). Each sample was covered in the tissue lysis buffer included in the kit (between $180 \mu \mathrm{L}$ and $540 \mu \mathrm{L}$ depending on tick size) and treated with proteinase $\mathrm{K}(20 \mu \mathrm{L} / 180 \mu \mathrm{L}$ of tissue lysis buffer) and then incubated at $56^{\circ} \mathrm{C}$ for $48 \mathrm{hr}$. Subsequent steps were carried out according to the manufacturer's instructions (Invitrogen, USA).

PCR: PCR amplification was performed in a final reaction volume $2 \mathrm{X}(50 \mu \mathrm{L})$ containing $25 \mu \mathrm{L} 2 \mathrm{X}$ master mix solution $(i$ $\mathrm{Taq}^{\mathrm{TM}}$, iNtRON, Korea), $0.2 \mathrm{uM}(2 \mu \mathrm{L})$ of each primer, $4 \mu \mathrm{L}$ template DNA, $2.5 \mu \mathrm{L}$ Bovine serum albumin, $\& 14.5 \mu \mathrm{L}$ injection $\mathrm{H}_{2} \mathrm{O}$. The designated primers were obtained from Macrogen, Korea. The oligonucleotide sequences of the primers used for detected Theileria annulata were forward strand primer30-kDa N516 gene (5'- GTA ACC TTT AAA AAC GT-3') and reverse strand primer $30-\mathrm{kDa}$ N517 gene (5'- GTT ACG AAC ATG GGT TT-3') (D'Oliveira et al, 1995) under an initial denaturation at $94^{\circ} \mathrm{C}$ for $10 \mathrm{~min}$ followed by 30 cycles of denaturation at $94^{\circ} \mathrm{C}$ for $1 \mathrm{~min}$, annealing at $55^{\circ} \mathrm{C}$ for $1 \mathrm{~min}$, and at $72^{\circ} \mathrm{C}$ for $1 \mathrm{~min}$, followed by final extension at $72^{\circ} \mathrm{C}$ for 10 min. Amplification reactions were done in 
a PCR thermal cycler Biometra T-personal/Germany S/N 1003507 and the corresponding amplicons were checked on $1 \%$ agarose-gel using TAE buffer stained with ethidium bromide, examined under UV transilluminator, and photographed using the Digital Camera.

\section{Results}

Four ixodid tick species detected on one

Table 1: Prevalence of ticks on one-humped camels in Birqash village from December 2014 to November. 2015.

\begin{tabular}{|l|c|c|c|c|c|c|c|c|c|}
\hline \multirow{2}{*}{$\begin{array}{l}\text { Month of } \\
\text { collection }\end{array}$} & $\begin{array}{c}\text { No. of } \\
\text { examined } \\
\text { camels }\end{array}$ & $\begin{array}{c}\text { Infested } \\
\text { No. }\end{array}$ & $\begin{array}{c}\text { Infested } \\
(\%)\end{array}$ & $\begin{array}{c}\text { Infested } \\
\text { No. }\end{array}$ & $\begin{array}{c}\text { Infested } \\
(\%)\end{array}$ & $\begin{array}{c}\text { Infested } \\
\text { No. }\end{array}$ & $\begin{array}{c}\text { Infested } \\
(\%)\end{array}$ & $\begin{array}{c}\text { Infested } \\
\text { No. }\end{array}$ & $\begin{array}{c}\text { Infested } \\
(\%)\end{array}$ \\
\hline Dec 2014 & 25 & 14 & 56 & 1 & 4 & - & - & - & - \\
\hline Jan 2015 & 25 & 12 & 48 & - & - & - & - & - & - \\
\hline Feb 2015 & 24 & 8 & 33 & - & - & - & - & - & - \\
\hline Mar 2015 & 25 & 15 & 60 & 2 & 8 & 1 & 4 & - & - \\
\hline Apr 2015 & 25 & 16 & 64 & 2 & 8 & 1 & 4 & - & - \\
\hline May 2015 & 25 & 21 & 84 & 4 & 16 & 1 & 4 & - & - \\
\hline Jun 2015 & 25 & 23 & 92 & - & - & - & - & - & - \\
\hline Jul 2015 & 25 & 23 & 92 & 4 & 16 & 3 & 12 & 3 & 12 \\
\hline Aug 2015 & 25 & 21 & 84 & 5 & 20 & - & - & 4 & 16 \\
\hline Sep 2015 & 26 & 19 & 73 & - & & 3 & 12 & - & - \\
\hline Oct 2015 & 24 & 19 & 79 & 4 & 17 & - & - & - & - \\
\hline Nov 2015 & 24 & 15 & 63 & 3 & 13 & - & - & - & - \\
\hline Total & 298 & 206 & 69 & 25 & 8 & 9 & 3 & 7 & 2 \\
\hline
\end{tabular}

There was a distinct monthly prevalence of each species in the studied area. H. dromedarii was observed to be more prevalence from May to October. A. lepidum infested lower number of camels than $H$. dromedarii, with peak prevalence in August. But, two peak periods were reported for $A$. variegatum, one in July and second in September. $R$. pulchellus was recorded in July

and August. Also, there was a marked increase in the number of $H$. dromedarii on camels examined between June and October, which declined to a minimum number in February. The relative numbers of the total tick of the four species recorded were H. dromedarii, 92.3\%; A. lepidum, 5.2\%; A. variegatum, $1.8 \%$ and $R$. pulchellus, $0.6 \%$.

Table 2: Abundance of ixodid ticks on camels in Birqash village from December 2014 to November 2015.

\begin{tabular}{|c|c|c|c|c|c|c|c|c|c|c|c|}
\hline \multirow{3}{*}{$\begin{array}{l}\text { Month of } \\
\text { collection }\end{array}$} & \multirow{3}{*}{$\begin{array}{c}\begin{array}{c}\text { No. of } \\
\text { camels } \\
\text { examined }\end{array} \\
25\end{array}$} & \multirow{2}{*}{\multicolumn{2}{|c|}{$\begin{array}{c}\text { H. dromedarii } \\
\text { No. of ticks } \\
\left(q+0^{\lambda}\right)\end{array}$}} & \multirow{2}{*}{\multicolumn{2}{|c|}{ 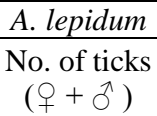 }} & \multirow{2}{*}{\multicolumn{2}{|c|}{$\begin{array}{c}\text { A. variegatum } \\
\text { No. of ticks } \\
(q+\hat{0})\end{array}$}} & \multirow{2}{*}{\multicolumn{2}{|c|}{$\begin{array}{c}\text { R. pulchellus } \\
\text { No. of ticks } \\
(q+\hat{0})\end{array}$}} & \multirow{3}{*}{$\begin{array}{c}\begin{array}{c}\text { Tick } \\
\text { number }\end{array} \\
100\end{array}$} & \multirow{3}{*}{$\begin{array}{c}\text { Ticks } \\
(\%)\end{array}$} \\
\hline & & & & & & & & & & & \\
\hline & & 75 & 24 & 0 & 1 & - & - & - & - & & \\
\hline Jan 2015 & 25 & 50 & 11 & - & - & - & - & - & - & 61 & 3.9 \\
\hline Feb 2015 & 24 & 30 & 14 & - & - & - & - & - & - & 44 & 2.8 \\
\hline Mar 2015 & 25 & 60 & 13 & 0 & 3 & - & - & - & - & 76 & 4.9 \\
\hline Apr 2015 & 25 & 64 & 5 & 2 & 0 & - & - & - & - & 71 & 4.6 \\
\hline May 2015 & 25 & 75 & 37 & 3 & 6 & 0 & 3 & - & - & 124 & 8 \\
\hline Jun 2015 & 25 & 127 & 50 & - & - & - & - & - & - & 177 & 11.4 \\
\hline Jul 2015 & 25 & 130 & 32 & 2 & 23 & 0 & 22 & 0 & 3 & 212 & 13.7 \\
\hline Aug 2015 & 25 & 177 & 42 & 2 & 32 & - & - & - & - & 253 & 16.4 \\
\hline Sep 2015 & 26 & 168 & 10 & - & - & 0 & 3 & 0 & 7 & 188 & 12.2 \\
\hline Oct 2015 & 24 & 141 & 10 & 1 & 3 & - & - & - & - & 155 & 10 \\
\hline Nov 2015 & 24 & 65 & 12 & 2 & 0 & - & - & - & - & 79 & 5.1 \\
\hline Total & 298 & 1162 & 260 & 12 & 68 & - & 28 & - & 10 & 1540 & \\
\hline
\end{tabular}

Number of A. lepidum and A. variegatum was relatively low but increased in July and
September. R. pulchellus appeared in July and September. Proportion between ticks' 
number and climatic conditions increased in camels at high temperatures (Fig. 1).

Th. annulata infected camels showed no abnormal clinical picture. Hemolymph sm- ears examination of 20 female $H$. dromedarii $(1.3 \%)$ was positive for $T h$. annulata, while smears of A. lepidum, A. variegatum and $R$. pulchellus were negative.

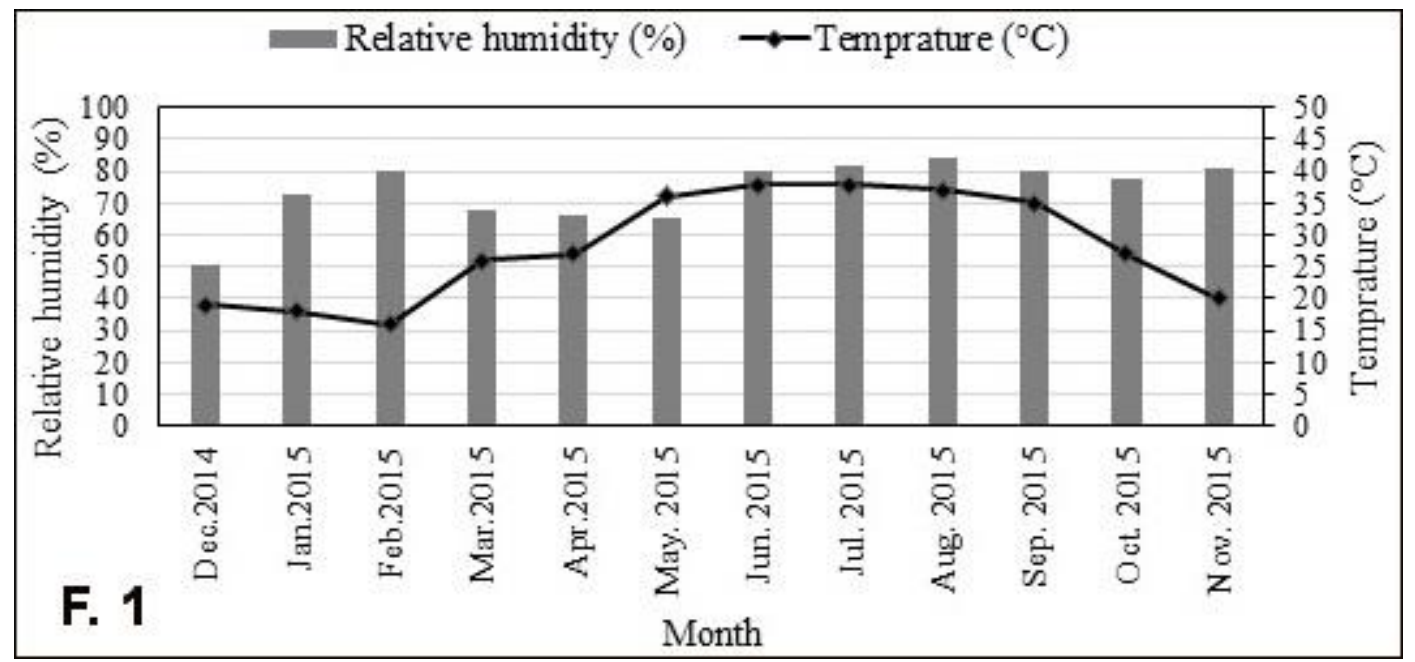

Fig. 1: Ambient temperature and relative humidity recorded in study area from Dec. 2014 to Nov. 2015

Theileria annulata were observed in $H$. detection of nucleic acid of Th. annulata dromedarii with highest infestation rate in summer and relatively few in autumn and spring, whereas none during winter season (Tab. 3). The 20 Giemsa-stained hemolymph smears positive were examined for the using one primer for Th. annulata. The PCR identified 20 positive samples for $T h$. annulata, bands appeared at $750 \mathrm{bp}$ were consistent with the expected size for PCR products in Theileria sp. (Fig. 2).

Table 3: Positive Theileria infection in ixodid ticks using Giemsa stain in different seasons, 2014, 2015

\begin{tabular}{|l|c|c|c|c|c|c|c|}
\hline \multirow{2}{*}{ Tick species } & \multirow{2}{*}{$\begin{array}{c}\text { Tick num- } \\
\text { ber }\end{array}$} & \multicolumn{6}{|c|}{ Theileria positive number } \\
\cline { 3 - 8 } & Hinter & Springer & Summer & Autumn & Total & Theileria (\%) \\
\hline H. dromedarii & 1422 & - & - & 20 & - & 20 & 1.4 \\
\hline A. lepidum & 80 & - & - & - & - & - & - \\
\hline A. variegatum & 28 & - & - & - & - & - & - \\
\hline R. pulchellus & 10 & - & - & - & - & - & - \\
\hline Total & 1540 & - & - & 20 & - & 20 & 1.3 \\
\hline
\end{tabular}

Molecular detection of Th. annulata in Geimsa-stain positive $H$. dromedarii was done by PCR using primer set N516/N517

derived from gene encoding $30 \mathrm{kDa}$ major merozoite surface antigen that amplified Th. annulata at 750 bp (Fig. 2).

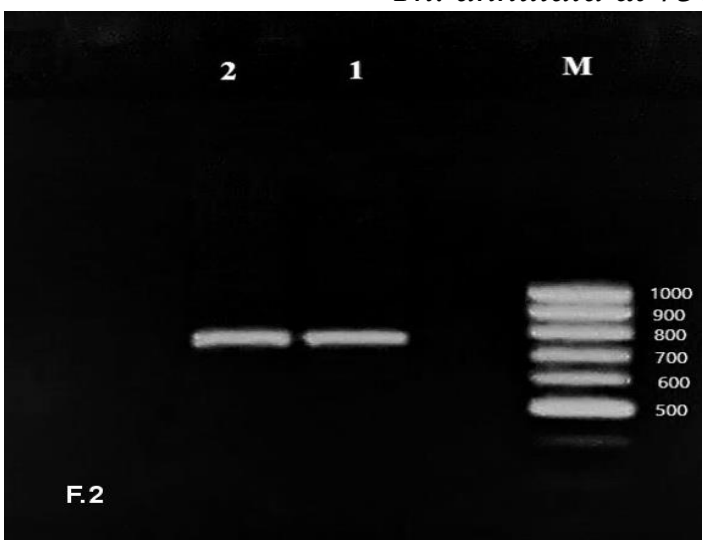

Fig. 2: PCR showing diagnostic bands for Th. annulata at 750 bp lane M 100 bp Ladder = DNA marker. 


\section{Discussion}

Camels were selected in the present study, because of their distribution in most African countries and also due to their economic importance. They are considered the main host for many species of ixodid ticks that occurred in Africa (El Bahnasawy et al, 2012). Egypt is a permanent importer of camels from many African countries such as Sudan, Ethiopia, Nigeria and Somalia. Thousands of camels enter Egypt every year where these camels are carried different species of ticks where some of them probably not present in Egypt (Abdullah et $a l, 2016)$. Some of tick species that come to Egypt with imported camels may infest local camels or other domestic animals. The changes in weather that became more hot and wet in Egypt during the last years probably induce the imported tick species to adapt and become endemic in Egypt (Mazyad and Khalaf, 2002).

The economic damage of ixodid ticks to camels does not restrict to blood sucking but it includes the most fatal tick-borne theileriosis disease, beside other bacterial and protozoal diseases (Dautel, 1999; Dantas-Torres et al, 2012). Therefore, the tick fauna on the camels should be updated from time to time to avoid the problems induced from ticks and tick borne diseases in an appropriate time.

In the present study, a total of 298 camels were examined for ixodid tick infestation. Four tick species, H. dromedarii, A. lepidum. A. variegatum, and $R$. pulchelluswere recorded on camels. The camel tick $H$. dromdarii gave highest prevalence rate (69\%). This tick species is considered the commonest tick on Egyptian camels either local bred or imported ones. The three tick species gave low prevalence rate between 2 to $8 \%$. This low prevalence rate may be due to their weak adaptation to the Egyptian environmental conditions. Meanwhile, these tick-species was not recorded before on the local camels or other domestic ones in
Egypt, but, Amblyomma spp. was recorded on imported camels (Barghash et al, 2016).

Hyalomma dromedarii on the camels was more prevalence from May to October, while, A. lepidum infested was in August. However, A. variegatum was in July and September, $R$. pulchellus was in July and August. Umar et al. (2011) in Nigeria examined 410 camels found high prevalence in $H$. dromedarii (58\%) and low in $A$. variegatum (42\%) and $R$. pulchellus $(25 \%)$. They stated that the environmental conditions in Nigeria were more suitable for survival and development of $A$. variegatum and $R$. pulchellus, and that $H$. dromedarii was more prevalence from May to October, A. variegatum was more prevalnce in July and $R$. pulchellus was recorded in June and October.

In the present study, $H$. dromedarii represented the main tick species infesting the camels $(92.3 \%)$ followed by A. lepidum (5.2\%), A. variegatum (1.8\%) and then $R$. pulchellus $(0.6 \%)$. Besides, H. dromedarii females were found engorged on the examined camels, while females on A. lepidum, $A$. variegatum, and $R$. pulchellus were not found or rarely partially engorged. This could be due to the fact that camels are not the preferred hosts for these tick species. But, Elghali and Hassan (2009) in northern Sudan, reported $H$. dromedarii $(88.9 \%)$ as the main tick species infesting camels. Also, Semere et al, (2014) reported that $R$. pulchellus the most abundant tick species $(92.7 \%)$ on the examined camels that represented $53.7 \%$ of all collected ticks. The low prevalence of this tick in the present study might be due to the fact that $R$. pulchellus is a tick of savanna and desert climitic regions as the commonest tick species in the Rift Vally areas. Also, H. dromedarii was $(42.7 \%)$ and constituted $12.8 \%$ of collected ticks. In the present study, H. dromedarii was the commonest tick species and it was reported in desert climates where camels live (Walker et al, 2003). On the 
other hand, El-Bahnasawy et al. (2013) in Egypt stated that in the $21^{\text {st }}$ Century, vector-borne infectious diseases was accepted as the disaster issues with considerable significant morbidity and mortality that must be considered by public health, veterinary and agricultural authorities.

In the present study, the annual prevalence of tick infestation was $69 \%$. The prevalence of tick infestation on the dromedary camels in eastern Ethiopia and Iran was $94 \%$ and $59.25 \%$, respectively (Taddese $e t$ al, 2013; Moshaverinia and Moghaddas, 2015). The difference in the rate of prevalence in three areas could be attributed to different climatic conditions and particularly differences in the sampling periods.

In the present study, $H$. dromedarii was the predominant species found in infested camels $92.3 \%$, and this agreed with Youssef et al, (2015) who reported high prevalence of $H$. dromedarii in Egypt. Hyalomma dromedarii proved to be the principal vector of Theileria spp. in vertebrates (Hoogstraal, 1956). This parasite has various developmental stages, different shapes and forms inside the ticks. These forms were in the hemolymph as ring form, slender spine-like form and round form (ElRefaii et al, 1998; Hamed et al, 2011). There were no clinical pictures in all examined camels, but this disagreed with Hamed et al. (2011) who reported that $3 / 15$ camels infected with Theileria had enlargement of superficial lymph node and fever.

In the present study, Theileria species developmental stages were found in $6.56 \%$ (101/1540) of tick-hemolymph. This result disagreed with Hamed et al, (2011) who found $9.38 \%(21 / 224)$ in examined tickhemolymph. Such variations may due to different localities, examination season, camels' population density, sampling different periods and climatic conditions.

In the present study, the primer set N516/N517 derived from the gene encoding the $30 \mathrm{kDa}$ major merozoite surface antigen was used in molecular diagnosing of T. annulata in Geimsa positive H. dromedarii ticks. This gene was used in molecular studies to detect $T$. annulata in either animals (Abd Ellah and Al-Hosary, 2011;

Ganguly et al, 2015; Youssef et al, 2015; Majidiani et al, 2016; Sudan, et al, 2016) or ticks (Jacquiet et al, 1990; D'Oliveira et al, 1997). All these studies used this gene in PCR screening confirmed that the camel tick $H$. dromedarii proved to be the main vector of $T h$. annulata. They found fragment 721 bp closes with the fragment 750 bp that was recorded in this study.

\section{Conclusion}

Some parasitic zoonoses are confined to certain geographic areas in Egypt, such as the deserts and the Sinai Peninsula. Animal reservoirs of parasitic zoonoses were identified, particularly rodents, stray dogs and stray cats as well as mosquitoes and ticks and other vectors, which constitute a potential risk of disease transmission.

Based on the outcome results, the camels mostly harbor Hyalomma dromedarii. This species is the most notorious ticks for the transmission of animal diseases. Thus, appropriate tick control measures are needed to employ and pour-on the method for acaricide application.

\section{References}

Abd El-Baky, SMM, 2001: Prevalence of external parasites in the south-eastern desert of Egypt. J. Egypt. Soc. Parasitol. 31, 1:223-32.

Abd Ellah, MR, Al-Hosary, AAT, 2011: Comparison of primer sets for amplification of $30 \mathrm{kDa}$ merozoite surface antigen of bovine theileriasis. J. Anim. Vet. Adv. 10, 12:1607-9.

Abdullah, HH, El-Molla, A, Salib, FA, Allam, NA, Ghazy, AA, et al, 2016: Morphological and molecular identification of the brown dog tick, Rhipicephalus sanguineus and the camel tick, Hyalomma dromedarii (Acari: Ixodidae) vectors of rickettsioses in Egypt. Vet. World 9, 10:1087-101.

Barghash, SM, Hafez, AA, Darwish, AM, ElNaga, TRA, 2016: Molecular detection of pathogens in ticks infesting camels in Matrouh Governorate, Egypt. J. Bacteriol. Parasitol. 7: 259-62.

Bishop, R, Musoke, A, Morzaria, S, Gardn- 
er, M, Nene, V, 2004: Theileria: intracellular protozoan parasites of wild and domestic ruminants transmitted by ixodid ticks. Parasitology 129:271-83.

Burgdorfer, W, 1970: Hemolymph test, a technique for detection of Rickettsiae in ticks. Am. J. Trop. Med. Hyg. 19:1010-4.

Dantas-Torres, F, Chomel, BB, Otranto, D, 2012: Ticks and tick-borne diseases: One hea1th perspective. Trends Parasitol. 28:437-46.

Dautel, H, Kahl, O, 1999: Ticks (Acari: Ixodoidea) and their medical importance in the urban environment. In: Proceedings of the $3^{\text {rd }}$ International Conference on Urban Pests, Prague, Czech Republic: Czech University of Agriculture 73-82.

De la Fuente, J, Estrada-Pena, A, Venzal, J M, Kocan, KM, Sonenshine, DE, 2007: Overview: ticks as vectors of pathogens that cause disease in humans and animals. Front. Biosci. 13:6938-46.

D'Oliveira, C, van der Weide, M, Habela, M A, Jacquiet, P, Jongejan, F, 1995: Detection of Theileria annulata in blood samples of carrier cattle by PCR. J. Clin. Microbiol. 33, 10: 2665-9.

D'Oliveira, C, Van Der Weide, M, Jacquiet, P, Jongejan, F, 1997: Detection of Theileria annulata by the PCR in ticks (Acari: Ixodidae) collected from cattle in Mauritania. Exp. Appl. Acarol. 21, 5:279-91.

El-Bahnasawy, MM, Sabah, AA, Saleh, HA, Morsy, TA, 2012: The tick-borne CrimeanCongo hemorrhagic fever in Africa, Asia, Europe, and America: what about Egypt? J. Egypt. Soc. Parasitol. 42, 2: 373-84.

El-Bahnasawy, MM, Megahed, LA, Saleh, HA, Morsy, TA, 2013: The Rift Valley fever: could re-emerge in Egypt again? J. Egypt. Soc. Parasitol. 43, 1:41-56.

El-Kady, GA, 1998: Protozoal parasites in tick species infesting camels in Sinai Peninsula. J. Egypt Soc. Parasitol. 28, 3:765-76.

El Kammah, KM, Oyoun, LM, El Kady, G A, Shafy, SA, 2001: Investigation of blood parasites in livestock infested with argasid and ixodid ticks, in Egypt. J. Egypt Soc. Parasitol. 31:365-71.

El-Fayoumy, MM, Abou-Elnga, TR, Abd ElBaky, SM, Abdout, A, 2005: Prevalence and treatment of camel theileriosis and its vector tick in North Coast of Egypt. Egypt. Vet. Med. Ass. 65:291-2.
Elghali, A, Hassan, SM, 2009: Ticks (Acari: Ix-odidae) infesting camels (Camelus dromedarius) in Northern Sudan. Onderstepoort J. Vet. Res. 76:177-85.

El-Refaii, AHM, Wahba, AA, Shehab, JG, 1998: Studies on Theileria infection among slaughtered camels in Egypt. Egypt. J. Med. Sci. 19:1-17.

Florin-Christensen, M, Schnittger, L, 2009: Piroplasmids and ticks: a long-lasting intimate relationship. Front. Biosci. 14:3064-73.

Ganguly, A, Bhanot, V, Bisla, R, S, Ganguly, I, Singh, H, et al, 2015: Hematobiochemical alterations and direct blood polymerase chain reaction detection of Theileria annulata in naturally infected crossbred cows. Vet. World 8, 1:24-8.

Hamed, MI, Zaitoun, MA, Ahmaed, ElAllawy, A, A, Taha, Mourad, I, Mourad, 2011: Investigation of Theileria camelensis in camels infested by Hyalomma dromedarii ticks in Upper Egypt. J. Adv. Vet. Res. 1:4-7.

Hoogstraal, H, 1956: Notes on African Haemaphysalis ticks. III. The hyrax parasites, $H$. bequaerti sp. nov., H. orientalis N. and W, 1915 (new combination), and $H$. cooleyi Bedford, 1929 (Ixodoidea, Ixodidae). J. Parasitol. 42: 156-72.

Jacquiet, P, Dia, ML, Perie, NM, Jongejan, F, Uilenberg, G, et al, 1990: Presence de Theileria annulata en Mauretanie. Rev. Elev. Med. Vet. Pays Trop. 43:489-90.

Kamani, J, Usman, TA, Onyeamaechi, EG, Usman, MA, Kida, SM, 2008: Hemoparasites of camels (Camelus dromedarius) in Maiduguri, Nigeria. Anim. Res. Int. 5: 838-9.

Majidiani, H, Nabavi, R, Ganjali, M, Saadati, D, 2016: Detection of Theileria annulata carriers in Holstein-Friesian (Bos taurus taurus) and Sistani (Bos taurus indicus) cattle breeds by polymerase chain reaction in Sistan region, Iran. J. Parasit. Dis. 40, 4:1184-8.

Mazyad, SA, Khalaf, SAA, 2002: Studies of theileria and babesia infecting live and slaughtered animals in $\mathrm{Al}$ Arish and El Hasanah, North Sinai Governorate, Egypt. J. Egypt. Soc. Parasitol. 32: 601-10.

Moshaverinia A, Moghaddas, E, 2015: Prevalence of tick infestation in dromedary camels (Camelus dromedarius) brought for slaughter in Mashhad abattoir, Iran. J. Parasit. Dis. 39, 3: 452-5. 
Nassar, MA, 1992: Theileria infection in camels (Camelus dromedaries) in Egypt. Vet. Parasitol. 43:147-9.

Norbert, M, 2013: Future challenges for parasitology: Vector control and one health in Europe: The veterinary medicinal view on CVBDS such as tick borreliosis, rickettsiosis and canine leishmaniasis. Special Issue: One World Health -Veterinary Parasitology in the Twenty First Century $24^{\text {th }}$ WAAVP Conference. Vet. Parasitol. 195:256-71.

Semere, K, Nesibu, A, Yisehak, T, Birhanu, H, 2014: Hard Ticks of Camel in Southern Zone of Tigray, Northern Ethiopia. J. Parasitol. Vector Biol. 6: 151-5.

Shaw, MK, Tilney, LG, Musoke, AJ, 1991: The entry of Theileria parva sporozoites into bovine lymphocytes: evidence for MHC class I involvement. J. Cell Biol. 113:87-101.

Sudan, V, Jaiswal, AK, Parashar, R, Shanker, D, 2016: PCR based unraveling of the cryptic epizootiology of bubaline theileriosis targeting the merozoite surface antigen gene. Indian J. Anim. Sci. 86, 3:235-7.

Swelum, AA, Ismael, AB, Khalaf, AF, Abo- uheif, AM, 2014: Clinical and laboratory findings associated with naturally occurring babesiosis in dromedary camels. Bull. Vet. Inst. Pulawy J. 58:229-33.

Taddese, A, Mustefa, M, Fikru, A, 2013: Prevalence and identification of camel ticks in eastern Ethiopia. Online J. Vet. Res. 17:64-72.

Umar, YA, George, BDJ, Ajanusi, OJ, 2011: Survey of Hard ticks (Ixodidae) infesting Onehumped camels (Camelus dromedarius) in Kano State-Nigeria. Nigerian J. Parasitol. 32:61-6. Walker, AR, Bouattour, A, Camicas, JL, et al, 2003: Ticks of domestic animals in Africa. Edinburgh, UK: Bioscience Reports.

Youssef, SY, Yasien, S, Mousa, WM, Nasr, S M, El-Kelesh, EA, et al, 2015: Vector identification and clinical, hematological, biochemical, and parasitological characteristics of camel (Camelus dromedarius) theileriosis in Egypt. Trop. Anim. Hlth. Prod. 47:649-56.

Zhang, X, Liu, Z, Yang, J, Chen, Z, Guan, G, et al, 2014: Multiplex PCR for diagnosis of Theileria uilenbergi, Theileria luwenshuni, and Theileria ovis in small ruminants. Parasitol. Res. 113, 2:527-31 